\title{
1. Introduction to Law and Economics for Civil Law Systems
}

\section{CAN THE LAW DO EVERYTHING?}

' $\ldots$ it is a fundamental principle with the English Lawyers, that Parliament can do every thing, except making a Woman a Man, or a Man a Woman.' de Lolme wrote in $1771 .{ }^{1} \mathrm{He}$ meant to express the supremacy of the English Parliament. Two centuries on, medical science has advanced on making a Woman a Man, or a Man a Woman, and the power of Parliament is no longer considered as absolute as it then looked, but is limited by fundamental rights defined in constitutions, charters and international conventions that the courts have the power to apply against acts of Parliament.

But de Lolme's saying lends itself to a different reading as well: law can do everything. To bring about any desired social situation, on this view, it suffices to legislate it. To judge by the staggering pace at which legislation is being produced these days, modern governments appear to draw their inspiration from this second reading. A positivist approach to law handily complements this line of thinking. Yet the very fact that such massive amounts of legislation appear to be necessary suggests that citizens are not playing the game; that law does not always produce the effect considered desirable.

An example: minimum wage laws. Consider, for instance, legislation setting the minimum wage. It proceeds from the distressing observation that some persons cannot decently live on the wages they are making. The remedy seems simple enough: oblige employers to pay a minimally acceptable wage to anyone they wish to hire. The intention appears generous: help the least well off.

Yet what is the effect? The Congressional Budget Office of the US Congress has attempted to estimate, in a 2019 Report, the effects of increasing, in six small steps between 1 January 2020 and 1 January 2025, the federal minimum wage from its current rate of $\$ 7.25$, to $\$ 10, \$ 12$ or $\$ 15$ in 2025 , increases of 38 per cent, 66 per cent and 107 per cent respectively. ${ }^{2}$ This should increase the

\footnotetext{
De Lolme 1784, t. 1, c. X, 134.

2 Congressional Budget Office 2019.
} 
income of an estimated $3.5 \mathrm{M}$, respectively $11 \mathrm{M}$ and $27 \mathrm{M}$ American workers, on a population of $330 \mathrm{M}$ citizens and growing. ${ }^{3}$ The Report also estimates how many persons would jump over the poverty threshold as a result: negligible for the increase to $\$ 10,0.4 \mathrm{M}$ persons for the increase to $\$ 12$, and $1.3 \mathrm{M}$ for the increase to $\$ 15$.

But the increase would also have negative effects. It would make some jobs disappear: up to $100 \mathrm{~K}$ in the case of an increase to $\$ 10,300 \mathrm{~K}$ for the $\$ 12$ increase and 1.3 $\mathrm{M}$ for the $\$ 15$ increase. The contribution of some workers to a firm's output-which sets the upper limit of what the firm can afford to pay a worker-may in some instances be less than the newly set minimum wage. Firms employing workers below the newly set minimum wage must increase their prices to cover cost. This would tend to reduce the quantity sold of their product and to make consumers who do buy it pay more for it. In the longer term, the firms who now employ persons below the minimum wage will have to let some of them go and may hire fewer new workers. They may bring in more machines to replace labour that has become more expensive (substitution effect). For the workers who are let go, there is a net loss, even if unemployment insurance may soften the blow in the short run. It may not be easy to find an alternative job.

One can, of course, extend government control to cover layoffs as well, but this merely displaces the problem. Being stuck with too many workers that cannot be let go, at 'too high' wages, the 'marginal' firm may have to close its doors, or automate more and hire fewer, but better qualified workers at higher wages. Obstacles to firing persons will translate into a disincentive to hire them in the first place; no employer likes to be stuck with labour considered too expensive for the job. All in all, a minimum wage law will tend to reduce the number of available jobs but reserve them to persons who are better qualified and earn higher wages.

Who are the workers that are affected? One group are the young entering the labour market, having no work experience yet; another, those who re-enter the labour market after a long absence, for instance to raise a family. The minimum wage creates long-term unemployment amongst these groups. It may give them incentives to look for work in the grey or black market (including the distribution of drugs), where labour is not subject to the minimum wage.

These predictions can be empirically verified and this has been done in numerous studies covering many different countries. For instance, a Quebec study in the 1990s concludes that a 10 per cent increase of the minimum wage leads to an average increase of 1.3 per cent in the unemployment rate

3 https://en.wikipedia.org/wiki/Demography_of_the_United_States, accessed 4 August 2021. 
amongst the young and those re-entering the labour market. ${ }^{4}$ A multitude of studies confirm these effects. ${ }^{5}$ Moreover, the poorest households are unlikely to benefit from the increase.

Unemployment of 20 per cent and higher amongst young persons has dramatic long-term consequences, as it may prevent many from acquiring, whilst accepting modest entry wages, the experience that will allow them to climb the social ladder to more responsible and remunerative work. It may entail long-term unemployment, which is particularly demoralising and may have dramatic social consequences, such as violent riots. Some may drop out of the welfare state altogether.

There is a link between the minimum wage and welfare payments offered to the indigent. As welfare payments are raised, certain low-wage positions no longer look attractive: why work if you can get virtually the same money without working? Personal dignity and work ethic will not withstand this logic for very long. Certain jobs are 'priced out of the market'.

These are surely not the effects sought by the well intentioned who hope to help the poorest by raising the minimum wage. But they are the foreseeable consequences of that policy, that the economic analysis of law is forced to call to our attention. Of course, if the minimum wage is raised in small increments only, more or less at pace with inflation, one produces a very visible symbolic effect, whose negative side effects, though not absent, are virtually imperceptible. ${ }^{6}$

Why then do western governments regularly vote such increases? Ignorance cannot be the explanation. Perhaps the positive symbolic effect largely overshadows the veiled harmful ones.

Would some groups have an interest in making low-paying jobs disappear? That might be the case for 'organised (mostly unionised) labour'. A minimum wage increase may reduce overall employment but will raise the wage level for the remaining jobs immediately above that level and may be used in collective negotiations as a benchmark. Moreover, for employers it becomes less attractive to hire unskilled workers; they will instead automate more and hire better-trained workers at higher wages. For these workers competition from unskilled workers is reduced, providing them with better wages and greater

4 Cousineau 1991; Neumark 2008; 2014a; for an overview of the arguments in the debate: http://en.wikipedia.org/wiki/Minimum_wage\#Debate_over_consequences; IZA 2009 (http://www.iza.org/index_html?mainframe=http $\% 3 \mathrm{~A} / / \mathrm{www}$. iza.org/ conference_files/EMW2009/viewProgram\%3Fconf_id\%3D1657\&topSelect=events\& subSelect $=\overline{\text { conferences}}$, , both accessed 4 August $20 \overline{2} 1$.

5 For a survey, see Neumark 2014b; 2014c; for Canada, Murphy 2016.

6 As highlighted in The Economist of 15 August 2020, Economics Brief Minimum wages. 
job security. In this light, increases of the minimum wage are in the interest of labour unions; in empirical studies they are shown to be staunch supporters of such increases. ${ }^{7}$

The appropriate level of the minimum wage would hence be debated not so much in the labour market as in the 'political market.' If some stand to gain and others to lose as a result of a policy, the question is whom the politicians are most likely to listen to. On this score, 'organised labour' is much better placed than the unorganised unemployed, who are the victims of the minimum wage increase.

To be sure, the debate is not couched in terms of opposing interests of the two groups; everything is presented as a matter of social justice and solidarity, in the 'general interest' of society. Knowing the foreseeable effects of raising the minimum wage, one may well wonder why one should feel solidarity towards organised workers and not towards the others. At all events, it is obvious that the 'general interest' serves here as a cover for the pursuit of particular interests.

\section{UNDERSTANDING THE LAW}

The example of the minimum wage reminds us that 'law, like language, is not a gadget that can be fashioned at will' ${ }^{8}$ To properly understand the law, it is not sufficient, contrary to what a positivist approach might suggest, only to know all the legislative texts, international treaties and the associated case law, and to ensure that they form a seamless web without internal contradictions. ${ }^{9}$ One also needs to understand the constraints to be observed in lawyering to allow the law to fulfil its social function.

The function of the law is to articulate non-violent solutions to disputes and conflicts that may arise in the interaction amongst individuals in society, and to define the institutions whose mission it is to make those solutions prevail. ${ }^{10}$ Those institutions contribute to the nonviolent coordination of individuals' plans and actions. ${ }^{11}$ It is important to know whether legal rules in fact fulfil that function. To that end, one has to determine the social effects of existing rules and to predict those of planned reforms. Knowledge of those social effects may show the wisdom of some existing rules and temper our fervour to reform

\footnotetext{
For instance Oi 1997, 10.

Leoni 1991, 218.

Samuel 2003.

10 See for instance Fuller 1969, 106: law is the enterprise of subjecting human conduct to the governance of rules; Deumier 2015, 69, No. 69 .

11 O’Driscoll 1996, xxii.
} 
them. At the same time, it may bring to light rules that produce harmful effects and whose raison d'être should be questioned.

Legal education prepares one for mastering law texts, but scarcely for the study of their social effects. Such studies are considered to lie within the province of the social sciences. They are by no means trivial and one could scarcely assess the social effects of law without some specific training. To come back to our earlier example, an intervention in market prices, including salaries and wages, of which the minimum wage is one example, risks upsetting a delicate adjustment mechanism. Salaries are signals, indicating, to those who seek employment, the interest of working in this sector rather than that, and to those who may employ them the cost of employing a particular person for a particular job (as opposed to producing that good or service differently, or to produce something altogether different). An intervention in the prices-as a change of the minimum wage-reorients the decision of all those who rely on them as signals. The experience in the former socialist republics shows the vast repercussions, generally detrimental to ordinary citizens, of setting prices arbitrarily. The process by which prices are set and the legal framework that presupposes in a market economy-in particular, public order, suppression of fraud, property rights, enforceable contracts, money-incorporate a wisdom that lawyers would ignore at the peril of civil society.

Over the past half century, the spectacular development of information technology has provided lawyers with most effective means instantly and easily to find relevant legal documents from amongst ever-increasing masses of them throughout the world. For any given legal problem, one can now in little time and in one spot-the screen of one's computer, tablet or smart phone-bring together all relevant law texts and case law. Where, a century ago, the quantity of documents that could be effectively considered for any legal question was practically bounded by that to which one could have physical access, that constraint has popped today. That development has made viable the unbridled multiplication of law texts we observe today, reinforcing a positivist view of the law that sees it as exhaustively described in officially adopted written texts. At the same time, it may have led lawyers to move to the background any consideration of the social effects of rules.

The social sciences, that should provide lawyers with the tools to assess the social effects of rules, have not evolved at the spectacular pace of information technologies, that would have balanced the different components of lawyering. Speaking of the social sciences, it is important to stress the essential unity underlying them, as Elster has done recently. ${ }^{12}$ 'They all seek descriptively, or positively, to understand how humanly-created institutions (including laws)

12 Elster 2015; also Trachtman 2004, Ridley 2010, McCloskey 2016. 
affect behavior, and, normatively, to understand how changes in these institutions would affect behavior.' ${ }^{13}$

Amongst the social sciences, it is in our view economics that has made the most promising advances for law. There are several reasons for that: it has a well-developed theoretical framework (microeconomics); it provides currently the most advanced application of the rational choice model, which is one of the elements that unify the social sciences; it has given rise, as we shall see in the following chapters, to applications in all fields of law and its scientific literature continues to develop at a rapid pace in the hands of new generations of scholars who have taken over from the founders.

\section{LAW AND ECONOMICS -NATURE}

Linking law to economics will make some readers think of economic law. Economic law is a branch of law drawing together various strands of regulation of economic power: banks and money markets; competition; foreign trade; regulation of the professions; industry regulation; public utilities and state enterprises. To practise economic law, one has to draw on economic concepts, as the regulated subjects have a straightforward economic function.

Law and economics is quite different. It is not a field of law, nor an assortment of fields, but a method for understanding law, in all its branches, through its social effects, teased out with the help of concepts and theory borrowed from economics.

The current movement of law and economics or, more formally, the economic analysis of law, originated in the United States, in the late 1950s and early 1960s, with economists trying out their conceptual tools on legal phenomena, which until then had been taken to be fixed for considerations outside the realm of economics. Law attaches to behaviour it seeks to encourage or discourage rewards or penalties to that end. Legal rules thus send to individuals subject to them signals that modify the attractiveness of regulated behaviour by comparison to other courses of action. Law creates incentives or disincentives to particular courses of action. The postulate of rational choice, which economic theory imputes to individuals, allows one to predict how the latter will adjust their behaviour in response to changed legal rules. One thus gets a handle on the social effects of legal rules.

Two remarkable discoveries have fired the interest of lawyers in this approach. The first is that, in studying different institutions that are part of American common law in this light, researchers found that nearly all of the rules looked formulated as if the purpose was to maximise social welfare,

13 Trachtman 2004, 67. 
the target value to be maximised in economic analysis. This translates into the thesis of the efficiency of the common law, defended in particular by one of the founding fathers of law and economics, Richard Posner, from the very first edition of his treatise, published in 1972, and maintained, though perhaps somewhat softened, throughout its successive editions, including the ninth edition, in 2014. ${ }^{14}$ In recent editions, he adds: 'economics is the deep structure of the common law, and the doctrines of that law are the surface structure'. ${ }^{15}$

The second, related discovery is that rules formulated as if aiming to maximise social welfare, called efficient in economic parlance, often correspond to what lawyers' intuition would consider fair or just rules. Justice is a notoriously fleeting notion to lawyers. Hence it would seem thrilling to dispose of conceptual tools that give a handle on it, even to those still being trained as lawyers.

A simple example may illustrate the two discoveries. Imagine yourself living a half-century or so ago, when photographs were still taken on film and developed at specialised stores. You organise a trip to the Canadian North to film the polar bears, which a popular monthly has agreed to buy from you. Upon your return you have the pictures developed at the local photo development shop. They mess up and spoil your pictures. Should you be able to claim the full cost of your trip to the North-CAD $\$ 100,000$ or so-from them?

Lawyers would reason here in terms of foreseeability and fairness. Since the development shop could not foresee damages of such magnitude, it would be unfair to hold them liable for them. Many Civil Codes reflect this principle by limiting damages in contract to those that were foreseen or foreseeable at the time of contracting, save cases of intention to cause harm or of gross negligence. The French Code says so in art. 1231-1, the Quebec Code in art. 1613.

Economists tackle the problem by examining the incentives flowing from holding one party or, alternatively, the other party liable. Let us look at this, leaving to one side for the moment the possibility of shifting burdens between the parties through negotiation. If the development shop is liable for the full cost of the expedition, they may consider adopting elaborate precautions to avoid future mishaps of this sort and the ensuing liability for the future: closer supervision, more personnel, more sophisticated machines, and so on. The cost of these precautions would have to be spread over all clients-all of them, because the store cannot distinguish-through the price of developing films. Since this liability would be part of the law, one must presume that competing photo development agencies would adopt similar policies and hence that this would not change the nature of the competition. Alternatively,

14 Posner 1972, 98; 2014.

15 Posner 2011, 315. 
the development shop may consider insuring itself for losses such as these, if this were the cheaper option. Competitors would reason similarly. Again, all customers, including you yourself, would pay the cost in the form of higher prices. Whatever the shop's response, the customer gets off scot-free and need not take any special precaution against mishaps.

How do the incentives run if the customer is liable, that is, can claim no, or nearly no, damages from the development shop? The customer now has a clear interest in exploring ways of reducing the risk. Knowing the legal rule before the trip, the customer is expected to consider options such as taking multiple shots with different cameras of each scene; having films developed at different agencies; underwriting insurance for mishaps. The shop may not take any special precautions beyond what is necessary to ensure its good reputation with its client base in general.

In comparing the cost of precautions and insurance taken in either hypothesis, one easily convinces oneself that those associated with the second hypothesis (shop not liable) are less onerous because better targeted than in the first hypothesis, where they are implicitly imposed on a host of clients who have no need for them. The rule that minimises the cost associated with the loss of films, and that is 'efficient' in economic terms, is also the one that seems just to lawyers.

\section{LAW AND ECONOMICS-METHOD}

The example of the spoilt film points to the method that law and economics uses. Let us have a closer look, starting with the type of problem that can be addressed in a law and economic approach.

At the most basic level, the economic analysis of law can always help one spell out the main foreseeable consequences of a change in legal rules in terms of persons adapting their behaviour in response to that change. A second level of analysis aims to trace the rationale for existing rules; both of these uses were illustrated in the example of the minimum wage laws. A third use of law and economics is normative and focuses on the question of which rules we ought to have or whether existing rules are desirable or wise. Let us look at each of these uses in turn.

\section{The Effects of Legal Rules}

The first use of law and economics is to determine the main effects of a change of rule or, symmetrically, those of a rule that has been left unchanged. By way of example, for most of the 20th century, abortion was prohibited in nearly all developed countries, nominally in order to protect the sanctity of life. We have a rule here that prohibits particular acts as opposed to one that prescribes (such 
as the minimum wage rule) them or a suppletive one, that provides a solution if parties have not negotiated a different one.

What were the effects of this prohibition? The disturbing film Vera Drake sought to illustrate them. The prohibition has not stopped the desire of women to have unwanted pregnancies interrupted, but has driven it underground, towards more or less dangerous avenues. For the well-off, abortion was still available and could be performed under medically safe conditions, against suitable payment and a hypocritical procedure in which the operation would be dressed up as justified by medical necessity.

For the poor, the story was altogether different; they had to have recourse to backstreet abortionists, practising under risky medical conditions with frequent mishaps, which could land the pregnant women in hospital with potentially fatal infections. Abortionists, even if acting out of compassion with 'those poor girls', were subject to severe criminal sanctions if caught (possibly on the basis of information provided by the hospital where the aborted woman landed because of complications or even death). The net effect of the prohibition was not to make abortion disappear, but to drive it underground, leaving it less accessible, at greater human cost and above all with great discriminatory effect against the poor. One can only speculate how these dynamics change when abortion can be provoked by a simple pill. ${ }^{16}$

Recent American studies observe a correlation between the permission to seek abortion following the 1973 US Supreme Court decision in Roe v. Wade $^{17}$ and a subsequent drop in criminal behaviour in the latter part of the 20th century. They hypothesise that this may be due to fewer unwanted children being born and then raised in circumstances prone to lead to criminal behaviour. ${ }^{18}$

In a remarkable book dealing with the decline of violence over the course of human history, ${ }^{19}$ Pinker believes this thesis to be 'too cute to be true' ${ }^{20}$ Would not the possibility of having an abortion have reduced the cost of sex, leading to more pregnancies, which better educated or more disciplined women would have interrupted, but not those women who are less so and who are also less well placed to bring up children properly? If that were true, one should expect an increase in criminality in the 1980s and 1990s, at the time when children born after the Roe-decision of 1973 reached their difficult age. This is what one

16 The Economist of 5 March (https://www.economist.com/international/2020/03/ 05/abortions-are-becoming-safer-and-easier-to-obtain-even-where-they-are-illegal), accessed 4 August 2021.

17 Roe v. Wade, 410 US 113 (1973).

18 Donohue 2001; Sen 2007.

19 Pinker 2011.

20 Pinker 2011, 119-120. 
observes, according to Pinker. ${ }^{21}$ The general decrease in criminality observed, for which statistics by age group are available, is due to the generation born before the Roe-decision. The explanation of the decrease must be found, in his view, in the increased means afforded to the maintenance of public order and the gradual civilising process. ${ }^{22}$ In a 2019 article, Donohue and Levitt present a follow-up on their original 2001 study, covering the period of 1997 till 2014 and using the same methodology. ${ }^{23}$ In the 2001, they had a predicted a decline in crime rate due to legalised abortion of 1 per cent per year over the following two decades. ${ }^{24}$ The recent study concludes: "the implied crime decline due to legalized abortion over the ensuing 17 years was slightly greater than 20 per cent, with a cumulative impact of legalized abortion on crime of roughly 45 per cent' ${ }^{25}$ Overall, this debate illustrates how scientific knowledge advances, through open discussion, under the ultimate guidance of empirical data.

What we have done here, in the case of the prohibition of abortion, as in the earlier one of the spoilt film, is to apply the idea of rational choice in individual decisions, in interactions with others and in markets, to see what the foreseeable consequences of alternative rules are and to spot potential unintended side effects. To be confronted with the practical implications of policies that look attractive at first blush but have unanticipated side effects may change one's views. Impact analysis of this sort can almost always be performed and is usually informative.

Let us look at the steps taken to perform the analysis in the spoilt film case. Different rules have different implications for the persons subject to them. The postulate of rational choice suggests that persons saddled with a risk or other potential burden the law places upon them in a contractual setting will undertake steps to reduce that burden, whereas their contract partners may do nothing. The precautions actually undertaken and the insurance underwritten will vary according to the person on whom the law imposes the risk burden. A change of rule will cast its shadow on how parties negotiate a deal or structure their long-term relationship and which (groups of) persons they will want to deal with. All such effects are to be taken into consideration.

To trace these effects, it is usually helpful to contrast a rule with its opposite or with an earlier, different rule: consider what the shop would do if liable for

\footnotetext{
$21 \quad$ Pinker 2011, 121.

22 Pinker 2011, 121. Term taken from the title of Elias 2000.

23 Donohue 2019.

24 Donohue 2001, 415: 'Our results suggest that all else equal, legalized abortion will account for persistent declines of 1 percent a year in crime over the next two decades.'

25 Donohue 2019, 23. They claim that findings of François 2014 for Europe support their thesis.
} 
the risk, then what the customer would do. In proceeding as suggested, we implicitly build a basic model of the world in which individuals interact in the shadow of legal rules. The model abstracts, as all models do, from much practical detail of the real world in order to focus on what seems most relevant to the purpose at hand, here to understand the main effects of a legal rule. The model is suitable if it still captures the essence of what is being studied and provides insights not visible to the 'untrained eye'.

Economists are taught to formulate models in a more precise fashion, using mathematical language. This allows them to spell out more precisely the implications of the model and prepare the ground for empirical testing. While this may seem daunting to lawyers, who are not trained in this art, they should remember that this merely extends the logic just sketched for our simple model. Teasing out the effects of legal rules is an essential step in all forms of economic analysis of law.

\section{The Underlying Economic Rationale of Legal Rules}

The second type of analysis moves on to consider the reasons why we have the rules we do-their objective or purpose to correct failures, mismatches, lack of coordination that would occur without them. Knowing the objective, we may ask whether the rule is an adequate, or indeed the best, means of pursuing it. The rationale of a broad area of law infuses the way we look at concepts or doctrines that are part of it. For instance, if the overall rationale of civil liability law is taken to be minimising the cost of mishaps and of their prevention, we can examine the component doctrines of fault (negligence), causality, damages as proven, faculty of discernment, contributory negligence or strict liability to see how they make sense in this light. We thereby find their raison d'être from the perspective of the economic analysis of law.

Consider, by way of a more detailed example, the rule establishing limited liability for shareholders of commercial enterprises. At first blush, this rule might seem to give an unfair shake to ordinary creditors, increasing the risk that they will not recover their debts. But consider the alternative rule of shareholders being liable without restriction for the debts of the enterprise. If you are a wealthy shareholder owning a large portion of the shares of the enterprise, you stand to lose a good bit of your personal fortune should the enterprise become insolvent. This has two important consequences. First, in order to invest, you will want to be sure that the return on the capital you invest is high enough to offset the risk you assume of having to cover debts of an insolvent enterprise; a shareholder owning only a small number of shares is not exposed to the same level of risk and hence may be satisfied with a smaller return. Second, you will want to supervise those who may affect this risk: other shareholders and managers. Where the company seeks to attract more capital and 
hence more shareholders, you may want a say in how much additional capital and which shareholders would be acceptable (pursuing policies not increasing your risk). All of this would make investing risky and time-consuming for the investor. Fewer ventures would go forward and hence fewer business opportunities would arise for those who would be ordinary creditors.

Now let us see how these considerations play out under limited liability. Since shareholders know their liability to be limited to the capital they undertake to supply, the risk is circumscribed. Shareholders can acquire shares in different companies so as to diversify their holdings and thereby reduce the overall level of risk they are exposed to. The risk per share now being circumscribed, the value of the share depends mostly on the expected profit, given the riskiness of the particular line of business. This in turn facilitates the creation of a market in which shares can be traded: sellers and buyers may attach somewhat different values to them, given their desire to diversify and the other shares they already hold in their portfolios (why else would they trade?), but prices at which the shares are traded would converge on values reflecting all publicly available information about the success of the enterprise's business plan by comparison with the industry as a whole. If the enterprise performs poorly, the share price will go down and make a takeover bid-and subsequent reorganisation-attractive for potential buyers.

For this logic to work, it is not necessary for every shareholder to keep a watchful eye over the enterprise's activities; it is sufficient that some do and trade on what they learn by supervising: share price movements will alert all takers to the perceived quality of management. Poor managers, being sacked after a takeover, will find their reputation blemished and hence the salaries they can command limited as they seek employment elsewhere. This would give them an incentive to provide the best management they can come up with. Overall, the limited liability rule reduces the costs for investors of providing capital, or symmetrically, the cost of attracting capital for enterprises needing it. The reduction of the cost of capital will make possible the realisation of business plans that might not be viable under unrestricted liability; in other words, it will tend to encourage innovation.

What about ordinary creditors? More innovation means more business for them. They will incorporate the risk of not being paid in the price of their ware or services, like an implicit insurance premium, taking into account that such risk is circumscribed given the multilateral supervision and that there are incentives for good management resulting from the structures just discussed.

Overall, the analysis allows us to discern the underlying rationale for limited shareholder liability: it allows a greater number of entrepreneurial initiatives to go forward than would otherwise be possible. It is plausible to think that welfare improvements in a society (growth) are positively related to the amount of entrepreneurial risk-and hence innovation-undertaken, 
even though a fraction of ventures fails, but is largely compensated by those that succeed. To sum up, the rule of limited liability of shareholders could be rationalised as tending to reduce the cost of capital and to stimulate innovation as a result.

It is easy to conceive of variants of this approach. Many rules of enterprise law may be explicable as safeguards for the providers of funds against misuse and other forms of opportunism by the managers actually handling the funds (all these safeguards would tend to reduce the cost of capital).

This problem must surely have been known in earlier times and so one may surmise that the Romans also faced it and developed rules for it in projects requiring substantial input of capital, such as colonisation of far-away locales. But no such rules have been transmitted to us in the codifications of Roman law. From here it is only one step to a doctoral research project-undertaken at my University-to trace the presence of such rules through descriptions of cases of abuse and remedies developed against it described or alluded to in later public speeches and historical accounts. ${ }^{26}$

What have we done here? Our initial analysis gave us a view of the effects of the legal rule we have and alternative rules in a greatly simplified world. That provides a summary justification for the existing rule. We then add some realism and consider what happens when we add the frictions that are part of the real world: uncertainty about the future and risk, transactions costs of various kinds, limitations of human rationality known as bounded rationality, the workings of the political process which may deviate from the pursuit of the general interest. ${ }^{27}$ Some moves that look tempting in the simplified view of the world may not be undertaken because of these frictions. Legal rules can often be rationalised as seeking to reduce such frictions and thereby to increase the range of exchanges and interactions individuals are willing to undertake.

One source of friction is prohibitive transactions costs-the costs of finding partners; getting to an agreement, in particular in large groups; of making sure that contracts will be performed as agreed, against the temptation by some of making a 'killing' by opportunistically reneging on an earlier commitment. Information asymmetries between parties to a contract may open the door to other forms of opportunism, such as free riding, public goods, moral hazard, holdouts, and to their prevention.

Transactions costs may evolve over time. Advances in transportation and in information and communication technologies may lower them. A rule that might have made sense as a correction for substantial transactions costs in

26 Dufour 2012.

27 On the enriched view of the world one gets by introducing these considerations, see Arcuri 2008. 
earlier times may cease to be justified when these costs change. Regulation of sewage disposal, water, electricity, telecommunications, that appeared justified so long as these industries looked like natural monopolies, cease to be apposite when technical advances make us realise that these services can very well be offered on a competitive basis. Or, by way of an historical example of a startling change in transactions costs, consider how in 1978 new communications technologies made possible for the first time to organise widespread grassroots opposition to the proposal for a tax increase in California, known at the time as proposition $13 .{ }^{28}$ The proposition was rejected during the subsequent referendum.

Bounded rationality, which behavioural economists have drawn attention to ${ }^{29}$ is another source of friction. It may prevent individuals from correctly perceiving a gain they might make or a trap they might fall into; the legal rule being analysed may be designed to help individuals overcome the effects of these misperceptions, by mandating the provision of relevant information or prohibiting transactions considered potential traps that individuals might too easily fall into.

Adding these refinements may not always be sufficient to give us a clear picture of why we have the rules we do, as we saw in the example of minimum wage legislation. We may then have to bring in a different kind of refinement, namely the trappings of the political market. Some persons or organised groups may succeed in using the political process to gain advantages they could not realise in open exchange. In the case of minimum wage legislation, this seemed to give us an explanation for the regular increase of the minimum wage in spite of the foreseeable deleterious effects.

In bringing in these various refinements, we draw on a 'tool kit' ${ }^{30}$ of economic theory, scenarios, sequences of events or templates: individual rational choice and the limitations brought to light by behavioural economics research, interactions amongst individuals as studied by game theory and in a more particular setting, microeconomic theory of markets and risk, slants introduced by recourse to the political process, appearance and traits of black markets, and so on. We will deal with these in the first part of the book.

We can also use as 'templates' the analyses of particular legal institutions and the rationales discovered for their existence, set out in later parts of the book. These broad rationales, which are really, as we shall discover, expressions of efficiency in particular contexts, include: for civil liability rules, mini-

28 http://en.wikipedia.org/wiki/California_Proposition_13_(1978), accessed 4 August 2021.

29 For a recent summary, Zamir 2018.

30 Term used by Farnsworth 2007. 
mising the cost of accidents and their prevention; for property rights, providing incentives for good husbanding of scarce resources and for inventing new and profitable uses for them, so as to bring resources to their highest valued uses; for contract law, reducing transactions costs beyond what parties could themselves accomplish, by improving the allocation of risks between parties, discouraging opportunistic behaviour, encouraging exchange of information of various sorts, and so on.

The process of adding further detail to our model may have to be repeated once or several times before we reach a satisfactory analysis of the rule at hand. It may happen that different strands of the economic analysis of law point to opposite conclusions as regards the efficiency of a rule being analysed, as we shall see for instance later in the book in the case of intellectual property. If so, the controversy cannot be resolved by conceptual analysis and intuition alone. Empirical analysis will have to tell.

Empirical analysis is more complicated and time-consuming than the purely conceptual analysis referred to above. Keeping in mind what sort of data are available or can be collected, one must spin out the theoretical model in the direction of available data, to state precisely what one should observe if the model were true, what if it were not. Where opposite predictions can be derived from different strands of the economic analysis of law, one should spell out what observations lend support to one thesis, what to the opposite one. An example of such an analysis in the field of consumer protection rules is provided by Wright, concluding that in most cases analysed consumers act more rationally than behavioural economists predicted and hence that the protective rules studied turn out to be a cure costlier than the disease they were supposed to remedy. ${ }^{31}$

Empirical analysis requires a set of specialised skills: formulation of models, experimental (where one wishes to rely on laboratory experiments) or observational techniques (for field work), methods of data analysis, and so on. Current legal training in most places does not prepare lawyers for such tasks and hence lawyers will have to collaborate with economists for such research. Collaboration presupposes a common vocabulary in which to communicate objectives and results, and an understanding of what the other discipline is able to contribute.

Much of the current attraction of law and economics is based on the insights provided by Level One conceptual analysis of legal concepts and their relationships. Ultimately, however, law and economics stands or falls with how well its models account for the reality we observe. The quality of the fit will have to

31 See Wright 2007. 
be settled in the last resort by empirical work. It is encouraging to see the steadily growing place of empirical analysis in the law and economics literature.

\section{The Desirability of Legal Rules}

As we ran through our last example of limited liability of shareholders, we imperceptibly reached the boundary of the normative use of the law and economics, aimed at judging whether particular rules are desirable or wise, or which rule is best from amongst several conceivable ones.

To clarify the point, let us return to our earlier analysis of the spoilt film. Common sense suggests that over the broad run of conceivable circumstances customers, having more intimate knowledge of the value of the film, are in a better position to take the appropriate precautions than the shop is. They are, in Calabresi's terms, the cheapest cost avoiders. ${ }^{32}$ As a simplifying rule that promises to minimise costs of mishaps in most instances, it makes sense to place the burden of precautions on those persons, as the French and Quebec Civil Code rule in fact do. In economic terms, on average no further rearrangement would promise to bring gains to both parties involved. The rule is 'efficient'.

Conceivably, there are circumstances in which this division of liability between the parties is not the best they themselves can think of. The development shop may be able to take on certain risks at a price below the cost they represent to their clients. The parties may vary in their ability to ensure the risks that cannot usefully be prevented. This points to a different way for parties to cope with the risk, which is for the store to ask customers if their film requires special care and in the affirmative, to charge a higher price or, alternatively, for the customer to take the initiative and reveal the high value of the film and ask for special care, or at what price the store is willing to guarantee flawless development. The parties may even agree on an amount of liquidated damages in advance. The point is that where parties are free to negotiate, they will tailor the contract to provide the division of precautions and risks that best corresponds to their willingness and ability to take them on. The shop will now adjust the price according to services the client asks it to render and risks to take on. By negotiating a different arrangement, parties signal that they expect gains beyond what the standard Code rule promised. Unless we suspect frictions that distort the process, this rule is the best we can come up with and we should let it stand, as in fact the Codes do under the doctrine of freedom of contract.

32 Calabresi 1970, 136f. 
Let us now look again at the example of the limited liability of shareholders. Our analysis led us to the conclusion that it has the apparent rationale of reducing the cost of capital, and, moreover, that all players whose situation we summarily looked at appear to be better off under this rule than under its opposite. There appear to be no losers, which makes it easy to judge that it is the best possible rule.

But the absence of losers is unusual. Most often a change of rule creates gains for some, losses for others. If so, we have to compare the gains and losses associated with the various conceivable rules and determine which has the greatest net advantage for society as a whole.

How do we gauge the various consequences of a rule to arrive at a single judgement about the rule, so that we can compare it with others? This question has given rise to considerable debate amongst economists. One proposal is to consider desirable any change of rule that produces a gain for all persons affected or, at worst, leaves their situation unchanged, but not worse. Such a change is called a Pareto gain (after the after the famous economist-sociologist Vilfredo Pareto (1848-1923), who proposed the idea). An economy in which all Pareto gains have been realised would be in a Pareto optimum. The notion of a Pareto gain should hardly be controversial since there are no losers, unless jealousy at other persons improving their lot is accepted as a loss. But in the latter case hardly any change would ever be judged beneficial for society. The disadvantage of the Pareto criterion is that it is very demanding. Many changes cannot be judged desirable as they produce at least one loser. Like a unanimity rule in collective decision-making processes, for practical policy-making purposes, this would be stifling. ${ }^{33}$

To escape this conundrum, a modified criterion has been proposed to which the names of the economists Nicholas Kaldor and John Hicks are associated. It provides that where the gains of a change more than offset the losses, the change should be judged desirable. If compensation were effectively paid, one would have a Pareto gain. But making the winners actually compensate the losers is itself, where large numbers of persons are involved, a costly and hence possibly stifling procedure. As a result the criterion has been further refined to provide that for a change to be judged desirable, it suffices for the gains to be large enough to offset the losses, even if no compensation actually takes place. Arguably, as more changes of this sort go forward, economic activity will pick up and in the long run all players stand to gain by this.

All the same, this Kaldor-Hicks potential compensation criterion leaves to be solved the problem of determining a common denominator into which 2015 .

33 On the delicate question of the philosophical status of the principle, see Farber 
all gains and losses can be translated for the purpose of the determining the balance. Values - of gains and of losses-are subjective and unless persons are seen to trade at a particular price, an outsider cannot determine the values they attach to particular options. At best, the outsider can make an intuitive expert estimate of what a reasonable person would be prepared to sell the items for. Market values for items that are readily available are at best a proxy; for more unique items, even this indicator may not be available. Of course, courts in deciding on the compensation to award for wrongdoing face this very problem of affording a specific compensation, indeed an amount of money, on various losses of subjective value-a personal injury, the loss of a pet, etc. The legal community everywhere is well aware of the trickiness of such judgements.

In spite of these drawbacks, the Kaldor-Hicks potential compensation test is largely accepted as the criterion by which to judge policies. To evaluate a policy, all gains and losses are set on a common denominator-usually money-and resulting value is used to compare this policy to others, evaluated in the same fashion. ${ }^{34}$

The Kaldor-Hicks test is related to the concept of efficiency: A set-up is said to be efficient if all moves that pass the Kaldor-Hicks test have been realised. When all profitable exchanges of this sort in the economy as a whole have been undertaken, the economy is said to have reached an optimum-the maximum welfare attainable within current knowledge and technology. Economists generally seek to investigate whether particular arrangements are efficient in this sense or whether a particular change could improve efficiency, i.e. provide gains that pass the Kaldor-Hicks test.

The restriction 'within current knowledge and technology' is important. In the Preface to a recent book, Cooter wondered which would have been more conducive to improving agricultural productivity, and hence human welfare, the efficient allocation of horse power pulling the plough, or the invention of the tractor. ${ }^{35}$ The invention of the tractor radically changed the scene, creating a wave of innovation which completely eclipsed possible gains from the more efficient use of horses. We will return to that question in dealing with intellectual property. All the same, it is important to look for efficient allocation of resources within the constraints of current knowledge and technologies.

The interest of this discussion is that Posner, from the very first edition of his treatise on the economic analysis of law, has put forth the thesis that all, or at least most, rules of the classical common law can be explained as efficient, and, moreover, that it is desirable for legal rules to be formulated so as to be efficient, or at least that where they are not, that discrepancy should call for

34 Trebilcock 2014.

35 Cooter 2014, Preface. 
justification. The early research agenda of law and economics has been to examine in detail whether existing rules can be shown to be efficient and if not, to propose changes that would make them so.

In putting the research agenda in this manner, we are imperceptibly moving across the boundary between descriptive and normative propositions and back, between is and ought, to use David Hume's terms. ${ }^{36}$ Hume's point was that what is desirable cannot be derived-logically-from what is; it requires a separate moral judgement. In examining whether particular legal rules are 'efficient' are we merely describing one of their essential characteristics, or are we passing moral judgement?

In more traditional legal scholarship, we might find that one rule applicable to a particular set of situations contradicts another equally applicable one. It is tempting to say that this is merely describing an important aspect of those rules-and one that might be exploited in pleadings before a court of law. Yet the absence of contradiction is such an overriding value in a legal system that lawyers are immediately moved to consider how the contradiction may be resolved-undoubtedly a normative viewpoint. Similarly, if efficiency is indeed a pervasive trait of legal rules, its absence in particular rules triggers calls for questioning that rule.

Posner's thesis of the efficiency of the classical common law is controversial. The jury is still out on the extent to which it actually holds and as much for common law as for civil law systems based on the French Civil Code in particular. ${ }^{37}$ All the same, most law and economics' practitioners would no doubt agree that there is a point to examining legal rules against the efficiency standard. Legal scholarship has an essential normative component.

The efficiency-of-the-common-law thesis is controversial for several reasons. First, it is difficult to judge all rules by the efficiency standard since some basic rules, such as those entitling individuals to their own person and labour, have to be fixed for the concept of efficiency even to be determinate. This consideration should not stand in the way of judging 'at the margin' a particular rule of contract, let us say, whilst all other rules are taken as fixed.

The second point of controversy is that setting legal rules may have redistributive effects which one would be ill-advised to ignore. The right conferred by law to a person or group of persons represent value, a form of wealth to them. If, for instance, the TRIPS Agreement were implemented by all countries, it would clearly lead to substantial transfers of wealth-as royalties for intellectual property-from developing to developed nations. Whilst this

36 Hume 1740, 469-470 (Book III, part I, section I (Moral Distinctions not deriv'd from Reason)).

37 Garoupa 2012. 
might seem justified by the presumed incentive effect for creating the objects of that intellectual property, it is hard to ignore the controversy the transfers will be-and are already-generating. Such a problem can be handled by the first and perhaps the second type of economic analysis sketched above (determining the effects, tracing the rationale of the rules) but the normative judgement may have to rely in part on criteria stemming from other sources. In a somewhat similar vein, it has been objected that whilst efficiency analysis would allow all values to be traded off to an extent ('at the margin'), our moral intuitions seem to require certain fixed starting points (no slavery or contract resembling it), whatever the apparent efficiency of the arrangement.

A third problem with the efficiency thesis is that it presupposes individual agents act fully rationally in their individual decisions and their interactions with others. Research in cognitive psychology and laboratory experiments suggests, as we shall see in the next chapters, that humans often simplify decision problems in ways that deviate from what the rational choice model would require. ${ }^{38}$ Some economic actors may attempt to take advantage of these deviations from rationality to make individuals 'fall into traps'. This prospect leads proponents of the Behavioural Law \& Economics group to suggest various forms of state intervention to correct for the deviations. Yet the jury is still out on the extent to which individuals actually fall into such traps. It is costly to be irrational and individuals may learn from experience how to avoid it. The rational choice model seems to us still to provide a good first approximation attributing to humans a predictable line of conduct.

All in all, whilst one must be wary of mechanically deriving normative judgements from efficiency considerations, there can be little question that lawyering involves normative judgements and that efficiency considerations usually point to meaningful aspects of such judgements, all the more so as efficient rules correspond often to what we intuitively consider to be fair or just.

\section{LAW AND ECONOMICS AND CIVIL LAW}

It has been argued that civil law systems are less amenable to economic analysis of law than are common law systems. ${ }^{39}$ To assess this claim, as this book deals mainly with civil law systems, we should first be clear about what distinguishes the two families of law.

What sets civil law systems apart from common law systems, besides differences in vocabulary, is that their core rules are spelt out in Codes drafted with the aim of covering in principle all relationships within the field of law they

39 Claim put forth in particular in Laporta 2008. 
govern. Any legal problem arising within that field is deemed to be soluble by reference to, and through interpretation of, one or more provisions of the Code.

Whilst Codes consolidate in their articles the solutions found to a great many practical problems that have arisen over time, it would be illusory to expect them to provide ready-made solutions for all conceivable problems. To cope with novel or imperfectly foreseen problems, whilst yet maintaining the claim to complete coverage, the Codes need to resort to a small number of open-ended concepts that can be used to fashion appropriate solutions to such problems. Good faith and abuse of rights are some of these concepts.

One of the main objectives of codification in civilian legal systems is to make law accessible: all the law for a given field is in principle to be found in one place - the Code - rather than in a proliferation of individual judicial decisions. This is meant to make it easier for citizens to know their rights and obligations. To accomplish this, the Codes need to be of a workable dimension. This entails that the formulas used will have to be concise and often abstract, condensing large ranges of practical solutions, and that the Code's provisions should be interpreted so as to form a coherent and seamless whole. One should not be misled by the abstract character of Code provisions or by the idea of the Code as a system. Codes are not systems of abstract logic unconnected with the real world; they are meant to reflect consolidated experience. To work effectively with such tools, civil lawyers need to be (made) aware of the gamut of actual cases each Code article is meant to capture as much as common lawyers need to be cognisant of the relevant the line of judicial decisions on a particular point of law.

Once these general characteristics are taken into consideration, one must expect the economic analysis of law to have as much to tell lawyers in civil law systems as it has those in common law systems, and in particular in the American legal system, where the current movement originated. The Legal Origins movement has forcefully put forth the thesis that common law systems are more conducive to economic growth than are civil law systems. ${ }^{40}$ This conclusion has been vigorously contested. ${ }^{41} \mathrm{~A}$ recent paper has highlighted how the imposition of the institutions of the French Revolution, including its Civil Code, on other European nations may have helped to clear rent-seeking barriers to trade. ${ }^{42}$ On the whole, the jury seems to be still out on the comparative virtues of different legal families.

La Porta 1998; 1999; 2008; 2013.

Dam 2006; Roe 2006; 2009; Milhaupt 2008; survey: Mackaay 2014.

2 Acemoglu 2011. 


\section{CONCLUSION: THE PLACE OF LAW AND ECONOMICS}

Law practice asks what legal rule is applicable to a given case and, possibly, what rule would be desirable. Law and economics asks what are the social effects of the applicable rule, ${ }^{43}$ and looks for its justification in terms of those effects. In a nutshell, that is the difference between the two but also their complementarity.

Written rules seek to provide persons subject to them a relative certainty as to what they may and may not do, thus allowing them to plan their affairs in a world marked by uncertainty. At the time of their adoption, the statutory or case-based rule presents a legal arrangement that lifts the uncertainty that would paralyse individual action, allowing individuals to go ahead with their projects. Contractual rules prospectively present gains for all contracting parties. For the certainty effect to produce its effect, persons concerned must be able to rely on it for a reasonable time. Formulating the rules in ordinary language serves to facilitate access for ordinary people. It would be considerably more cumbersome, at any point of doubt or dispute about the applicable law, to determine the efficient arrangement of the interests at stake according to the precepts of the economic analysis of law. Reliance on written rules, one might paraphrase, is parsimonious, economises on transaction costs in the very terms of law and economics.

The extraordinary flight of information technology provides us with almost instantaneous access to an immense wealth of legal rules. That risks relegating to the background considerations of the social function of the law. Yet such considerations ought to be part and parcel of a legal system based on the rule of law. One must therefore consider it essential to any law training to be familiarised with tools allowing one to assess the extent to which the law fulfils its social function.

What is the place of law and economics in a legal world that relies on the parsimony of law as texts? There can be no doubt that when time comes to reform the law, law and economics must have a prominent place. So also does it have a place in the task, given to doctoral students, of structuring a legal field that is emerging or evolving: consideration of the potential effect of rules, grouping rules according to similarity of their effects are of the essence of such structuring. Within scholarship on the positive law, law and economics can be a precious help in the regrouping and structuring of legal rules. Its aims are

43 'Perhaps the central contribution of the young discipline of law and economics is to provide a set of methods that allow analysts to assess the impact on private choices of shifts in legal rules.' Ferejohn 1992, 264. 
similar to those of codification and law reform. It can contribute to making a 'magma of rules' readable. ${ }^{44}$ In the application of the law before the courts, it can provide the foundation for a teleological interpretation of rules, by identifying the finality of the rule and proposing a reading that would do it justice. In the negotiation of complex contracts, familiarity with law and economics would predispose the lawyer, as an 'engineer of agreements', to be aware of the aims pursued by the client as well as the contracting partner, so as better to perceive the boundaries of the area where the agreement will have to be reached. Finally, where the existing rule appears seriously out of kilter with the circumstances prevailing when it was adopted, lawyers ought to dispose of an alarm system warning them that 'this will not work' and that a different reading of the law text or even its reform is apposite. Law and economics can provide such an alarm system.

\section{BIBLIOGRAPHY}

Acemoglu 2011: Acemoglu, Daron, Davide Cantoni et al., 'The Consequences of Radical Reform: The French Revolution', (2011) 101 American Economic Review 3286-3307

Arcuri 2008: Arcuri, Alessandra, 'Eclecticism in Law and Economics', (2008) 1 Erasmus Law Review 59-81

Calabresi 1970: Calabresi, Guido, The Cost of Accidents - A Legal and Economic Analysis, New Haven, Yale University Press, 1970

Congressional Budget Office 2019: Congressional Budget Office, The Effects on Employment and Family Income of Increasing the Federal Minimum Wage, Congress of the United States, Washington, 2019, https://www.cbo.gov/system/ files/2019-07/CBO-55410-MinimumWage2019.pdf

Cooter 2014: Cooter, Robert D., The Falcon's Gyre: Legal Foundations of Economic Innovation and Growth, Berkeley, California, Berkeley Law Books, 2014; http:// scholarship.law.berkeley.edu/books/1/

Cousineau 1991: Cousineau, Jean-Michel, 'L'effet du salaire minimum sur le chômage des jeunes et des femmes au Québec: une réestimation et un réexamen de la question', (1991) 67 Actualité économique 144-165

Dam 2006: Dam, Kenneth W., The Law-Growth Nexus: The Rule of Law and Economic Development, Washington, D.C., Brookings Institutions Press, 2006

De Lolme 1784: de Lolme, Jean-Louis, The Constitution of England, London, Robinson \& Murray, 1784, (4th ed.)

Deumier 2015: Deumier, Pascale, Introduction générale au droit, Paris, LGDJ, 2011

Donohue 2001: Donohue, John J. and Steven D. Levitt, 'The Impact of Legalized Abortion on Crime', (2001) 116 Quarterly Journal of Economics 379-420

Donohue 2019: Donohue, John J. and Steven D. Levitt, The Impact of Legalized Abortion on Crime Over the Last Two Decades, NBER Working Paper No. w25863, 2019, https://bfi.uchicago.edu/wp-content/uploads/BFI_WP_201975.pdf

44 Frison-Roche 2004, § 33. 
Dufour 2012: Dufour, Geneviève, Les societates publicanorum de la République romaine: ancêtres des sociétés par action modernes?, Montréal; Genève, Éditions Thémis; Schulthess, 2012

Elias 2000: Elias, Norbert, The Civilizing Process: Sociogenetic and Psychogenetic Investigations, New York, Wiley-Blackwell, 2000, (2nd ed.)

Elster 2015: Elster, Jon, Explaining Social Behavior: More Nuts and Bolts for the Social Sciences, Cambridge, Cambridge University Press, 2015, (2nd ed.)

Farber 2015: Farber, Daniel A., Autonomy, Welfare, and the Pareto Principle, in: Law and Economics: Philosophical Issues and Fundamental Questions, Aristides N. Hatzis and Nicholas Mercuro (dir.), London, Routledge, 2015, pp. 159-182

Farnsworth 2007: Farnsworth, Ward, The Legal Analyst: A Toolkit for Thinking about the Law, Chicago, University of Chicago Press, 2007

Ferejohn 2997: Ferejohn, John A. and Barry R. Weingast, 'A Positive Theory of Statutory Interpretation', (1992) 12 International Review of Law and Economics 263-279

François 2014: François, Abel, Raul Magni-Berton and Laurent Weill, 'Abortion and Crime: Cross-Country Evidence from Europe', (2014) 40 International Review of Law and Economics 24-35

Frison-Roche 2004: Frison-Roche, Marie-Anne, L'intérêt pour le système juridique de l'analyse économique du droit, Colloques, Cour de cassation, $2004 \mathrm{http}: / / \mathrm{www}$ .courdecassation.fr/formation br 4/2004 2034/anne frison 8184.html

Fuller 1969: Fuller, Lon L., The Morality of Law, New Haven, Yale University Press, 1969

Garoupa 2012: Garoupa, Nuno and Carlos Gómez Ligüerre, 'The Evolution of the Common Law and Efficiency', (2012) 40 Georgia Journal of International and Comparative Law 307-340

Hume 1740: Hume, David, A Treatise of Human Nature, Oxford, Clarendon Press, [1740], 1978, (2nd ed.)

IZA 2009: 'IZA Conference: The Economics of the Minimum Wage', (2009) IZA Compact 10-13 http://www.iza.org/index_html?mainframe=http\%3A//www .iza.org/conference_files/EMW2009/viewProgram\%3Fconf_id=1657\&topSelect= events\&subSelect $=$ conferences

La Porta 1998: La Porta, Rafael, Florencio López-de-Silanes, Andrei Shleifer and Robert Vishny, 'Law and Finance', (1998) 106 Journal of Political Economy $1113-1155$

La Porta 1999: La Porta, Rafael, Florencio López-de-Silanes, Andrei Shleifer and Robert W. Vishny, 'The Quality of Government', (1999) 15 Journal of Law, Economics, \& Organization 222-279

La Porta 2008: La Porta, Rafael, Florencio López-de-Silanes and Andrei Shleifer, 'The Economic Consequences of Legal Origins', (2008) 46 Journal of Economic Literature 285-332

La Porta 2013: La Porta, Rafael, Florencio López-De-Silanes and Andrei Shleifer, Law and Finance After a Decade of Research, in: Handbook of the Economics of Finance 2, George M. Constantinides and Milton Harris (dir.), Amsterdam, North-Holland, 2013, 425-491

Leoni 1991: Leoni, Bruno, Freedom and the Law, Indianapolis, Liberty Press, [1961], 1991, (3rd ed.)

Mackaay 2014: Mackaay, Ejan, 'La valeur des rapports Doing business aujourd'hui', (2014) 2014 La Revue de l'ERSUMA 111-136; http://revue.ersuma.org/IMG/pdf/ revue_de_1_ersuma_-_no4_special-idef.pdf 
McCloskey 2016: McCloskey, Deirdre N., Bourgeois Equality: How Ideas, Not Capital or Institutions, Enriched the World, Chicago, University of Chicago Press, 2016

Milhaupt 2008: Milhaupt, Curtis J. and Katharina Pistor, Law \& Capitalism: What Corporate Crises Reveal about Legal Systems and Economic Development around the World, Chicago, University of Chicago Press, 2008

Murphy 2016: Murphy, Robert P., Charles Lammam and Hugh Macintyre, Raising the Minimum Wage - Misguided Policy, Unintended Consequences, Vancouver, Fraser Institute, $2016 \mathrm{https} / / / \mathrm{www}$.fraserinstitute.org/sites/default/files/raising-the -minimum-wage-misguided-policy-unintended-consequences.pdf

Neumark 2008: Neumark, David and William L. Wascher, Minimum Wages, Cambridge, MA, MIT Press, 2008

Neumark 2014a: Neumark, David, 'Employment Effects of Minimum Wages - When minimum wages are introduced or raised, are there fewer jobs? Global evidence says yes', (2014) 2014 IZA World of Labor 1-10

Neumark 2014b: Neumark, David, J.M. Ian Salas and William L. Wascher, 'Revisiting the Minimum Wage-Employment Debate: Throwing Out the Baby with the Bathwater?', (2014) 67 Industrial and Labor Relations Review (ILR) 608-648

Neumark 2014c: Neumark, David, J.M. Ian Salas and William L. Wascher, More on Recent Evidence on the Effects of Minimum Wages in the United States, NBER Working Paper No. w20619, 2014, http://www.nber.org/papers/w18681.pdf

O'Driscoll 1996: O'Driscoll, Gerald P. and Mario J. Rizzo, The Economics of Time and Ignorance, London, Routledge, 1996, (2nd ed.)

Oi 1997: Oi, Walter J., 'The Consequences of Minimum Wage Legislation', (1997) 17 Economic Affairs 5-14

Pinker 2011: Pinker, Steven, The Better Angels of Our Nature: Why Violence Has Declined, New York, Viking, 2011

Posner 1972: Posner, Richard A., Economic Analysis of Law, Boston, Little, Brown and Cy, 1972, (1st ed.)

Posner 2011: Posner, Richard A., Economic Analysis of Law, New York, Wolters Kluwer Law \& Business, 2011, (8th ed.)

Posner 2014: Posner, Richard A., Economic Analysis of Law, New York, Wolters Kluwer Law \& Business (Aspen Casebook), 2014, (9th ed.)

Ridley 2010: Ridley, Matt, The Rational Optimist: How Prosperity Evolves, London; New York, Fourth Estate; Harper, 2010

Roe 2006: 'Legal, Origins, Politics, and Modern Stock Markets', (2006) 120 Harvard Law Review, 460-527.

Roe 2009: Roe, Mark J. and Jordan I. Siegel, 'Finance and Politics: A Review Essay Based on Kenneth Dam's Analysis of Legal Traditions in the Law-Growth Nexus', (2009) 47 Journal of Economic Literature 781-800

Samuel 2003: Samuel, Geoffrey, Epistemology and Method in Law, Aldershot, Ashgate, Dartmouth Publishing Co Ltd, 2003

Sen 2007: Sen, Anindya, 'Does Increased Abortion Lead to Lower Crime? Evaluating the Relationship between Crime, Abortion, and Fertility', (2007) 7 B.E. Journal of Economic Analysis \& Policy art. 48

Trachtman 2004: Trachtman, Joel P., 'The Methododology of Law and Economics in International Law', (2004) 6 International Law Forum du droit international 67-72

Trebilcock 2014: Trebilcock, Michael J., Dealing with Losers: The Political Economy of Policy Transitions, Oxford, Oxford University Press 2014 
Wright 2007: Wright, Joshua D., 'Behavioral Law and Economics, Paternalism, and Consumer Contracts: An Empirical Perspective', (2007) 2 NYU Journal of Law \& Liberty 470-511

Zamir 2018: Zamir, Eyal and Doron Teichman, Behavioral Economics and the Law, Oxford, Oxford University Press, 2018 